\title{
Research Paper Costs, returns and profitability of sapota in Thane district
}

\section{r.V. SURWASE, P.J. KSHIRSAGAR, J.M. TALATHI AND S.T. GORE}

See end of the paper for authors' affiliations

Correspondence to :

P.J. KSHIRSAGAR

Department of

Agricultural Economics,

College of Agriculture, Dr.

B.S. Konkan Krishi

Vidyapeeth,

Dapoli, RATNAGIRI (M.S.)

INDIA

Paper History :

Received : 16.09.2014;

Revised : 17.01 .2015

Accepted : 03.02.2015
ABSTRACT : The present study was conducted during 2013-14 in Thane district of Maharashtra. The cultivation of sapota of Dahanu and Palghar tahsils is concentrated near and away from the sea shore. Therefore, a cross sectional sample of 120 sapota growers was randomly selected and stratified in to two categories i.e. near the sea shore (Group I) and away from sea shore (Group II). The data were collected by personal interview method with the help of pretested schedule. The result revealed, at overall level per hectare total cost of maintenance (cost-C) of sapota orchard was worked out to Rs. 120138. The per hectare total cost of maintenance (cost C) of sapota orchard in group I was worked out to Rs. 125336 and Rs. 114452 in group II. The per hectare gross returns received at overall level of sapota orchard was Rs. 180572 and profit at different cost levels such as cost A, cost B and cost C were Rs. 127408, Rs. 69350 and Rs. 60434, respectively. The per hectare gross return was Rs.201260 in group I and Rs. 155901 in group II observed. It was observed that, at overall level net profit received at different cost levels such as cost A, cost B and cost C were Rs.145338, Rs.84644 and Rs.75924, respectively. Input-output ratio was 1.50 at overall level.

KEY WORDS : Cost, Returns, Profitability

HOW TO CITE THIS PAPER : Surwase, R.V., Kshirsagarm, P.J., Talathim, J.M. and Gorem, S.T. (2015). Costs, returns and profitability of sapota in Thane district. Internat. Res. J. Agric. Eco. \& Stat., 6 (1) : 96-99. 